ARTIGO

\title{
IDENTIDADE E DIFERENÇA NOS ESPAÇOS EDUCATIVOS INFANTIS
}

\author{
IDENTITY AND DIFFERENCE IN CHILDREN'S EDUCATIONAL SPACES
}

\section{IDENTIDAD Y DIFERENCIA EN LOS ESPACIOS EDUCATIVOS DE LOS NIÑOS}

\author{
Edmacy Quirina de Souza \\ Universidade Estadual do Sudoeste da Bahia - Brasil
}

Nilson Fernandes Dinis

Universidade Federal de São Carlos - Brasil

\begin{abstract}
Resumo: Este artigo busca analisar como os espaços e os discursos imagéticos revelam a questão racial e, como a criança, na condição de sujeito produzido culturalmente, experiencia as diferenças étnicoraciais no contexto da educação infantil. $\mathrm{O}$ viés metodológico interdisciplinar dos Estudos Culturais possibilitou entender o caráter discursivo e social das imagens. A pesquisa empírica aconteceu nos anos de 2013 e 2014, nas instituições de educação infantil (creches e pré-escolas) da rede municipal de ensino de Itapetinga, cidade situada na região Sudoeste da Bahia. As imagens foram coletadas em doze (12) instituições (creche e pré-escola). Os resultados da pesquisa apontam a existência de uma escola branqueada por meio de imagens (racismo imagético), que leva a uma institucionalização do branqueamento e naturalização da diferença, deixando de reconhecer a diversidade racial da escola e, ao mesmo tempo, de identificar que cada grupo racial tem sua singularidade, e, nesse sentido faz-se necessário a construção de uma identidade positiva da criança negra e a construção de uma educação antirracista.
\end{abstract}

Palavras-chave: Criança. Racismo. Imagem.

\begin{abstract}
This article seeks to analyze how spaces and imagetic discourses reveal the racial issue and, as the child, as a culturally produced subject, experiences ethnic-racial differences in the context of early childhood education. The interdisciplinary methodological bias of Cultural Studies made it possible to understand the discursive and social character of the images. The empirical research took place in the years 2013 and 2014, in early childhood education institutions (daycare centers and pre-schools) in the municipal education network of Itapetinga, a city located in the Southwest region of Bahia. The images were collected in twelve (12) institutions (daycare and pre-school). The research results point to the existence of a school whitened by means of images (imagetic racism), which leads to an institutionalization of whitening and naturalization of difference, failing to recognize the racial diversity of the school and, at the same time, to identify that each The racial group has its uniqueness, and, in this sense, it is necessary to build a positive identity for black children and to build an anti-racist education.
\end{abstract}

Keywords: Child. Racism. Image. 
Resumen: Este artículo busca analizar cómo los espacios y los discursos de imágenes revelan el problema racial y, como el niño, como sujeto culturalmente producido, experimenta diferencias étnicoraciales en el contexto de la educación de la primera infancia. El sesgo metodológico interdisciplinario de los estudios culturales permitió comprender el carácter discursivo y social de las imágenes. La investigación empírica tuvo lugar en los años 2013 y 2014, en instituciones de educación infantil (guarderías y preescolares) en la red de educación municipal de Itapetinga, una ciudad ubicada en la región suroeste de Bahía. Las imágenes fueron recolectadas en doce (12) instituciones (guarderías y preescolares). Los resultados de la investigación apuntan a la existencia de una escuela blanqueada por medio de imágenes (racismo imagético), lo que lleva a una institucionalización del blanqueamiento y la naturalización de la diferencia, al no reconocer la diversidad racial de la escuela y, al mismo tiempo, identificar que cada grupo racial tiene su singularidad, y en este sentido es necesario construir una identidad positiva para los niños negros y construir una educación antirracista.

Palabras clave: Niño. Racismo. Imagen.

\section{Introdução}

Identidade e diferença são temas que se encontram em voga. Identidade docente, identidade cultural, identidade negra, identidade do trabalhador, identidade sexual, ou respeito às diferenças, valorização das diferenças. Enfim, os conceitos identidade e diferença apresentam diversas ramificações.

Neste estudo, propomos uma análise do conceito de identidade racial no contexto escolar, apoiado nas imagens (fotos de painéis, gravuras) coletas nas instituições de educação infantil. Propomos discuti-los como constitutivos do espaço educativo, possibilitando desconstruir discursos homogeneizadores que sedimentam preconceitos no interior da escola. Numa aproximação com os Estudos Culturais, "compreendem-se os sujeitos como tendo identidades plurais, múltiplas; identidades que se transformam, que não são fixas ou permanentes, que podem até mesmo ser contraditórias" (LOURO, 2012, p. 28).

O Dicionário Analógico da Língua Portuguesa: ideias afins traz o significado de identidade como um conjunto de caracteres próprios, exclusivos de uma pessoa; fazer de duas coisas ou mais uma só. Apresenta igualdade, semelhança, autenticidade, conformidade, aderência, como palavras sinônimas de identidade o que nos faz pensar que identidade não comporta uma única significação e que se altera de acordo com o contexto histórico e cultural. Nesse dicionário, diferença, por sua vez, é aquilo capaz de distinguir uma coisa da outra; característica do que é diferente, desprovido de semelhança; que não possui nem demonstra igualdade; qualidade do que é diverso ou díspar; em que há diversidade; heterogeneidade (DICIONÁRIO, 2010). 
A racionalidade ocidental, arquitetada pela ciência moderna, nos conduz a uma busca constante de referências que servem de apoio ao estabelecimento de uma identidade fixa, inabalável e universal, ou seja, uma identidade do sujeito do sexo masculino e branco. Aprendemos com Hall (2004) que as velhas identidades já não dão conta de uma ancoragem estável e segura; há, hoje, o que ele chama de "crise de identidade". Em algumas perspectivas tradicionais, o indivíduo é totalmente centrado, unificado, dotado de capacidade, contínuo, segundo uma concepção individualista. Os discursos produzidos na história, quer do sujeito do Iluminismo, quer do sujeito sociológico, quer do sujeito pós-moderno, contribuem para que percebamos os nossos equívocos e erros e possamos rever nossas certezas, pois nada está pronto e acabado, nada mais é sólido e seguro.

A identidade para Hall (2012, p. 104) é um conceito polissêmico, e tudo o que leva ao essencialismo precisa ser colocado em desconstrução. Para ele, a "identidade é um desses que opera 'sob rasura', no intervalo entre a inversão e a emergência: uma ideia que não pode ser pensada de forma antiga, mas sem a qual certas questões-chave não podem ser sequer pensadas". Hall (2012) faz uma análise da articulação entre sujeito e práticas discursivas e propõe o conceito de identificação, enfatizando o processo de subjetivação e a política de exclusão que essa subjetivação parece implicar. A abordagem discursiva vê a identificação

[...] como uma construção, como um processo nunca completo - como algo sempre "em processo". Ela não é, nunca completamente determinada - no sentido de que se pode, sempre, "ganhá-la" ou "perdê-la"; no sentido de que ela pode ser, sempre, sustentada ou abandonada [...] a identificação é, ao fim e ao cabo, condicional; ao fim e ao cabo, alojada na contingência. Uma vez assegurada, ela não anulará a diferença (ibid., p. 106).

As categorias raça, etnia, diferença se constituem em discursos produzidos para legitimar hierarquias, poderes, verdades e saberes. Nesse sentido, propomos analisar a identidade e a diferença a partir das imagens que foram coletadas nas instituições de educação infantil, destacando o preconceito e o racismo explícito nas imagens.

Nessa trajetória, direcionada por uma investigação empírica, a pesquisa foi orientada pela seguinte problematização: Como os espaços e ambientes, as práticas imagéticas, discursivas e disciplinares revelam a questão racial? Como essa produção discursiva influencia na constituição de suas identidades?

O estudo teve como objetivo analisar como os espaços e os discursos imagéticos revelam a questão racial e como a criança, na condição de sujeito produzido culturalmente, experiencia as diferenças étnico-raciais no contexto da educação infantil. A análise investigativa se assenta nas produções imagéticas que ornamentam os espaços e os ambientes 
das instituições de educação infantil, particularmente painéis, fotos, gravura e que o seu espaço é caracterizado, majoritariamente, pela cultura eurocêntrica.

O que estamos chamando de "discurso imagético" é justamente a materialidade não linguística, ou seja, a análise discursiva de outros tipos de linguagem, neste caso em especial, as imagens fixas (fotografias, gravuras). Por meio das materialidades discursivas se processam as leituras dos textos imagéticos exibidos no contexto escolar. Segundo Sargentini e outros (2012, p, 214).), o texto imagético se apresenta como "unidade de significação constituída por sistemas semiológicos de natureza verbal (linguística) e não verbal (imagens estáticas e animadas, sons, sinais, símbolos, etc.) e pelo funcionamento enquanto unidade de expressão do discurso". O texto se constitui a "materialização concreta do discurso em uma ou em diferentes linguagens".

A pesquisa empírica aconteceu nos anos de 2013 e 2014, nas instituições de educação infantil (creches e pré-escolas) da rede municipal de ensino de Itapetinga, cidade situada na região Sudoeste da Bahia. As imagens foram coletadas nas doze instituições de educação infantil, cujos nomes foram modificados para garantir o anonimato. Optamos por designá-las com nomes de alguns/algumas teóricos/teóricas que discutem infância, relações raciais, diferença: Creche Maria Bujes, Creche Fúlvia Rosemberg, Creche Moysés Kuhlmann Jr., PréEscola Mariano Narodowski, Escola Stuart Hall, Pré-Escola Tomaz Tadeu da Silva.

Nas sessões de fotografia, procurávamos enquadrar o objeto selecionado junto com a criança para a qual tivéssemos tido permissão para fotografar ${ }^{1}$. Ainda que a fotografia se proponha a capturar a realidade como é, há uma manipulação, uma fabricação, pois "conhecemos os limites de um documento fotográfico, sabemos que ele mostra apenas aquilo que o fotógrafo quis enquadrar e aquilo que determinada luz e sombra lhe permitiu revelar" (MANGUEL, 2001, p. 92). Kossoy $(2012,79)$ afirma que "a fotografia, porém, não é apenas um documento por aquilo que mostra da cena passada, irreversível e congelada da imagem; faz saber também de seu autor, o fotógrafo, e da tecnologia que lhe proporcionou uma configuração característica e viabilizou seu conteúdo".

\section{Identidade e diferença na escola a partir da imagem}

Os discursos sedimentados nos estudos multiculturalistas evocam a convivência de diferentes grupos, culturas e etnias que buscam a preservação das identidades, mas sem abrir

\footnotetext{
${ }^{1}$ Informamos que os pesquisadores possuem, em seus arquivos, os termos de autorização de uso de imagem e depoimentos das crianças. Essas autorizações foram discutidas e assinadas pelos pais, mães e/ou responsáveis. Porém, aqui neste texto optamos por desfocar os rostos e quaisquer outras marcas de identificação.
} 
mão das diferenças. Essa identidade foge da concepção de sujeito unificado e móvel e se caracteriza como identidade híbrida (HALL, 2004). Nessa perspectiva, os discursos produzem significados sobre a realidade, por meio da cultura e das práticas sociais. Os discursos produzem a identidade e a diferença e são produzidos por elas dentro do contexto cultural numa relação constante de saber e poder. Diferenças, linguagem, cultura constituem-se em movimentos, cujos sentidos e significados sempre escapam.

Desse ponto de vista, a identidade étnico-racial só pode ser compreendida em sua conexão com a produção da diferença, a qual é concebida como um processo social discursivo. Identidade e diferença estão em conexão e estão sujeitas a vetores de forças e relações de poder. Elas nunca são inocentes. O que se deseja, na maioria das vezes, é uma identidade normal, natural, desejável e única - eu sou isso, eu sou aquilo, eu sou desse jeito, ou eu nasci assim, eu sou normal, eu sou branco/a, eu sou negro/a etc.

Para desconstruir essa visão normativa e fixa de identidade, Silva (2012, p. 96) sugere que

A identidade não é uma essência; não é um dado ou fato - seja de natureza, seja de cultura. A identidade não é fixa, estável, coerente, unificada, permanente. A identidade tampouco é homogênea, definitiva, acabada, idêntica, transcendental. Por outro lado, podemos dizer que a identidade é uma construção, um efeito, um processo de produção, uma relação, um ato performativo. A identidade é instável, contraditória, fragmentada, inconsistente, inacabada. A identidade está ligada a estruturas discursivas e narrativas.

Se a identidade do sujeito é constituída de acordo com as suas várias experiências, a escola deveria se portar como uma instituição de questionamentos, como um espaço que pode favorecer a discriminação ou possibilitar a valorização da construção da identidade. Se o sujeito tem uma experiência cultural diferente, por que ele tem de ser igual? Identidades culturais decorrem do nosso pertencimento a diversas culturas, diferentes etnias, línguas, religiões e nacionalidades. $\mathrm{O}$ fracionamento da identidade em múltiplas identidades não significa que elas sejam vividas harmonicamente.

Hall (2004, p. 13) sustenta que “dentro de nós, há identidades contraditórias, empurrando em diferentes direções, de tal modo que nossas identificações estão sendo continuamente deslocadas", construindo um "pluralismo de identidades". Essas identidades são, na maioria das vezes, "contraditórias ou não resolvidas" (ibid. p. 12), em razão das intensas e constantes interpelações dos sistemas sociais e culturais, que deslocam e descentram os sujeitos. 
Segundo Macedo (2010, p. 31), os sujeitos "constroem sua identidade no interior da cultura. Pertencer a uma cultura é tranquilizador porque permite a identificação com aquelas com que partilham estórias, memorias, imagens. Há tempos, a pluralização de culturas mostrou que não se pode ser um só, mas vários”.

Vejamos algumas imagens. A partir de agora, exploraremos melhor a construção dessas identidades dentro das escolas que atendem a crianças de 0 a 5 anos de idade. A Imagem 1 mostra um grupo de três crianças negras e, ao lado delas, colado no armário, um palhaço de cabelo loiro e, atrás das crianças, cinco figuras, que, pelo "corte" de cabelo, o tipo de camiseta, poderiam ser identificadas como de meninos brancos, mostrando as letras do alfabeto (as vogais).

Imagem 1. Creche Fúlvia Rosemberg

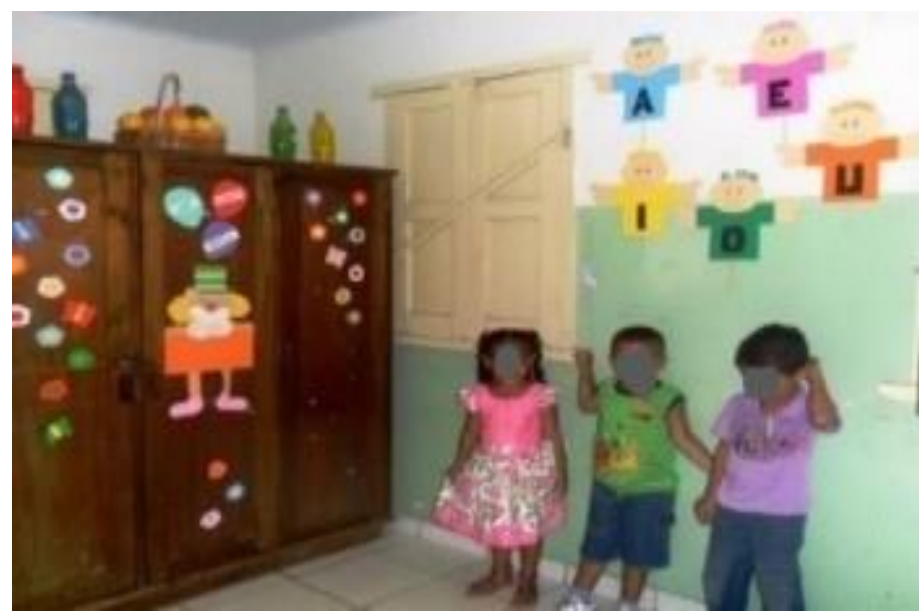

Fonte: Elaborada pelos autores

As tensões entre identidade e diferença no interior da escola, onde a diferença é vista como uma ameaça, algo indesejável, têm colocado o outro (aquele que é diferente de mim) numa posição de erradicação da alteridade.

As escolas, certamente, ainda vivem sob a égide da colonização, pois, além de considerar a brancura como a identidade normal, valorizam o gênero masculino. Por que o palhaço e os bonecos que exibem as vogais no corpo são masculinos? Em que lugar estão as meninas? A escola que, no início, separou católicos de protestantes, adultos de crianças, ricos de pobres (LOURO, 2013), negros de brancos, também separa meninos de meninas, privilegia a cultura branca e masculina. O impacto dessas escolhas sobre a identidade da criança é devastador.

Com as imagens projetadas nesses cartazes, a escola aponta aqueles que deverão ser modelos e permite que os sujeitos se reconheçam (ou não) nesses modelos. É preciso tornar 
visível, além da cultura e da imagem de crianças negras, mais meninas e negras, estas que foram ocultadas na história e continuam sendo ocultadas nas gravuras e cartazes. Uma escola que deixa emergir a diferença no seu cotidiano pedagógico contribui para a desconstrução das fixações da brancura e do sexismo, permitindo que a cultura apareça como uma prática para dar sentido à educação e ao mundo.

O cartaz da Imagem 2, que se encontra em um muro situado no fundo da creche, mostra duas crianças brincando, uma negra e uma branca. Podemos inferir que existe a representação da diversidade e a contemplação da diferença por aparecer a criança negra nesse contexto de negação de imagens de pessoas negras. Observamos, porém, que o garoto negro está empurrando a menina branca. Quem sabe, caracterizando o filho do empregado, empurrando a sinhazinha? Ele não poderia estar em outro balanço, brincando também?

Imagem 2. Creche Moysés Kuhlmann Jr

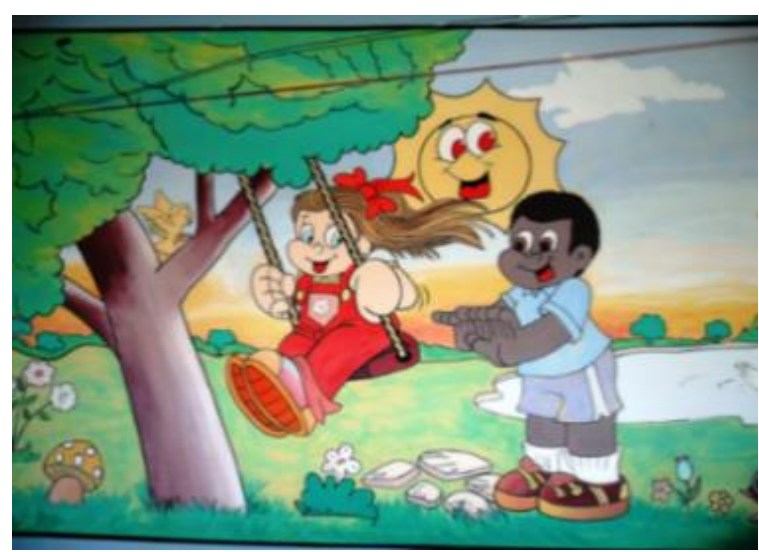

Fonte: Elaborado pelos autores.

As imagens contribuem para alargar as diferenças, pois a diferença, como a identidade, não é um fato da natureza, o que acontece em uma perspectiva de base essencialista; ao contrário, elas são construídas nas relações sociais e de poder que atravessam os sujeitos. Trabalhar com a diferença é apontar para a sua não neutralidade.

Estas exposições (painéis, imagens) não podem ser consideradas como produtos naturais ou desinteressados; elas são um artefato social, histórico, que está entrelaçado numa relação de poder e de luta pela manutenção da dominação étnico-racial eurocêntrica.

Na Imagem 3, há um grupo de crianças negras brincando de roda e, ao fundo, na Imagem 4, duas figuras de crianças desenhadas no muro da escola. É possível notarmos, nesta gravura, as características fenotípicas das figuras, uma situação que se constitui realidade comum nas escolas. Percebemos a questão da diferença como algo dado e fixo. É natural que as imagens tenham traços fenotípicos de pessoas brancas, enquanto as crianças sejam negras, pois elas 
precisam ver como funciona a realidade e precisam se adequar a ela. $\mathrm{O}$ diferente se constitui na criança negra, e não nas imagens brancas, e esta diferença, vista de modo exótico, só poderá ser representada nas imagens folclóricas, como a imagem lendária do Saci Pererê. Silva (2013) assegura que parece ser desejo nosso aparar as arestas do outro para torná-lo um mesmo, para fazê-lo caber em nossa normatividade, uma vez que o estranho e o diferente sempre nos trazem algo de inquietante.

Imagem 3. Pré-Escola Tomaz T. da Silva.

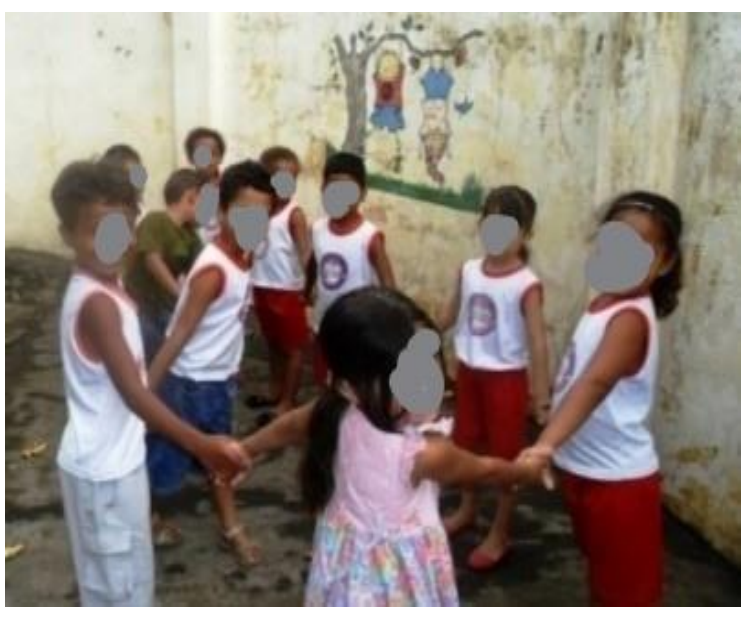

Fonte: Elaborado pelos autores.
Imagem 4. Pré-Escola Tomaz T. da Silva.

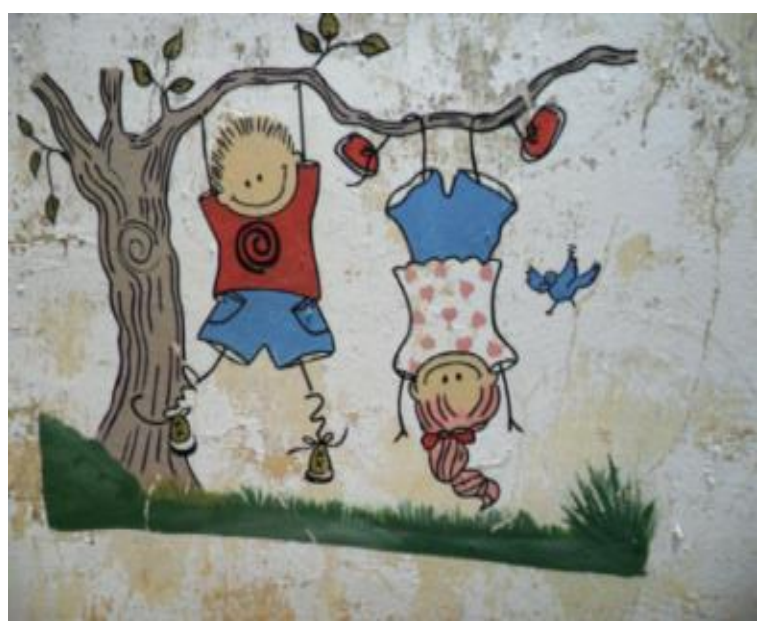

Fonte: Elaborado pelos autores.

Para Silva (2012, p. 74), “parece ser fácil definir a 'identidade' pelo aquilo que se é”, ou seja, quando se diz sou negro/a, tenho o nariz achatado, largo, estou afirmando a diferença, não sou branco/a, não tenho o nariz afilado. "As afirmações sobre diferença só fazem sentido se compreendidas em sua relação com as afirmações sobre identidade" (ibid. p. 75), e viceversa.

A identidade e a diferença estão ligadas a relações de poder, haja vista não haver um fundamento único para esses constructos. São construções históricas e discursivas que se manifestam num embate constante de jogo de forças, pois são, na maioria das vezes, “contraditórias ou não resolvidas" (HALL, 2004, p. 12), em razão das intensas e constantes interpelações dos sistemas sociais e culturais.

A identidade e a diferença nas instituições educativas vão além das questões de tolerância e respeito para com a diversidade cultural, pois a presença apenas desses "nobres sentimentos impedem que vejamos a identidade e a diferença como processos de produção social, como processos que envolvem relações de poder" (SILVA, 2012, p. 96). A tolerância aqui é entendida para além do suportar, associado ao politicamente correto. Muito mais do que 
tolerar deve-se promover condições para expor essas diferenças e criar possibilidades de múltiplas respostas para as mesmas.

Avtar Brah (2006), ao problematizar o conceito de diferença, compreende-o como categoria analítica e destaca quatro diferentes modos de ser conceituada: diferença como experiência; diferença como relação social; diferença como subjetividade e diferença como identidade.

Essas quatro categorias surgem em momentos e contextos variados, mas o interessante é notar que elas estão presentes nas escolas. A primeira, a diferença como experiência, está fortemente ligada ao feminismo, ao dar "voz coletiva às experiências pessoais das mulheres" (BRAH, 2006, p. 359), explorando as experiências individuais. "A experiência não reflete de maneira transparente uma realidade pré-determinada, mas é uma construção cultural" (ibid., p. 360), o lugar de formação do sujeito. Sabemos que os sujeitos são constituídos por meio das várias experiências, e estas, por serem diferentes, muitas vezes, são inferiorizadas, relegadas.

Sobre a segunda maneira de conceituar a diferença, Brah (2006, p. 362) a destaca como sendo a diferença uma relação social. Defende a maneira como a diferença é "constituída e organizada em relações sistemáticas através de discursos econômicos, culturais e políticos e práticas institucionais articulados e instituídos por diferentes regimes de poder”. Esta diferença pode ser entendida como as trajetórias históricas e contemporâneas das circunstâncias materiais e práticas culturais que produzem as condições para a construção das identidades de grupo. Essa diferença se reverbera quando legados da escravidão, do colonialismo ou do imperialismo são invocados.

Para Silvério (1999, p. 157), a escravidão moderna

Foi motivada economicamente, justificada religiosamente e naturalizada pela ciência do século XIX. No momento em que a colonização torna-se a alternativa de exploração econômica, a 'inferioridade' dos povos colonizados estava 'comprovada' cientificamente, cabendo, portanto, à cultura europeia com o apoio de seu aparato bélico e militar cumprir sua missão civilizatória.

A diferença como subjetividade modifica as concepções do sujeito como unificado, racional, centrado na consciência de homem universal, e faz emergir críticas nas diferentes direções, como os pós-estruturalistas, o feminismo, o anticolonialismo, o antirracismo, problematizando a "universalização das afirmações de verdade reivindicadas pelas grandes narrativas da história que colocam o 'homem' europeu em seu centro" (BRAH, 2006, p. 365). A subjetividade se constitui em um constante processo, e não como algo fixado e unificado. Nossa subjetividade é atravessada pelos discursos, que são culturais e históricos. 
E, por fim, a última categoria de análise: a diferença como identidade. Nesta, a autora revela que as questões de identidade estão "intimamente ligadas a questões de experiência, subjetividade e relações sociais [...]. As identidades são sinalizadas pela multiplicidade de posições de sujeito que constituem o sujeito. Portanto, a identidade não é fixa, nem singular; ela é uma multiplicidade relacional em constante mudança" (BRAH, 2006, p. 371).

Percebemos, com essa discussão de Brah, que essas quatro formas de conceituar a diferença não estão separadas, ora sendo uma coisa, ora sendo outra. Elas estão intimamente conectadas pelas experiências, pelas relações sociais, construindo as subjetividades e identidades dos sujeitos através dos contextos culturais. As diferenças não existem em si, não são essencialistas, elas são produzidas por meio de práticas e discursos que as significam, que lhes dão sentido. A diferença é nomeada em conformidade com um determinado lugar, que se coloca como referência. E aqui, esta referência é a escola.

A escola que nos foi legada pela modernidade está sedimentada na produção e reprodução da identidade e da diferença. Os novos grupos tidos como minoritários, que antes estavam excluídos desse espaço educativo, como mulheres e pessoas negras, agora começam a fazer parte e a requisitar transformações nos currículos pedagógicos e na organização escolar para atender às diferenças entre os sujeitos. Inserir no currículo uma discussão profícua sobre diversidade cultural, sexual, de gênero, de raça e etnia não é tão simples. Os currículos, programas, materiais e rituais pedagógicos privilegiam uma cultura normativa e branca, exemplificada pelos livros didáticos, já mencionados, e pelas próprias imagens discutidas neste trabalho.

Um dos traços que caracterizam a modernidade é o processo de individualização baseado na divisão social do trabalho e o desenvolvimento da sociedade privada regulando o espaço e o tempo dos indivíduos. Michel Foucault (1987) mostrou como o tempo e o espaço organizaram-se no século XVIII mediante o poder disciplinar nas escolas, mediando, avaliando e controlando os/as alunos/as, para transformá-los/as em corpos dóceis, que aceitam a discriminação e se calam diante da supremacia da cultura branca. A escola foi gestada como máquina capaz de fazer dos corpos o objetivo do poder disciplinar.

Segundo Louro (2002, p. 121),

O espaço não é um "cenário", mas é parte da trama, é um constituidor de sujeitos. As divisões que nele se estabelecem, o que se constrói e o que se faz vazio, os caminhos que se abrem e os muros que se edificam, o que põe perto ou longe, vizinho ou estrangeiro, os lugares que se estabelecem para os sujeitos, os móveis e objetos que se lhes destinam, por onde se permite ou proíbe ir - são criações que se transformam, que se ajustam as necessidades e 
interesses mutantes, que servem a alguns e não a outros, que implicam relações de poder.

Como um espaço atravessado por divisões sociais (gênero, etnia, classe, idade) que influenciam na constituição identitária do sujeito, a escola continua não apenas a produzir e a reproduzir diferentes sujeitos, como a multiplicar os desiguais. Projetos de regeneração e profilaxia social foram arquitetados conforme o pressuposto de que determinados sujeitos fogem aos modelos de "normais" e disciplinados. A disciplinaridade e seus resultados são vistos como naturais e necessários, e o espaço escolar, como espaço de regeneração, de formar corpos dóceis e produtivos.

A seguir, a Imagem 5, registrada na Creche Fúlvia Rosemberg, a qual atende a crianças de um (01) a três (03) anos de idade. Ao fundo, há duas bonequinhas sentadas no morango, que são denominadas maçãzinha (cabelo loiro) e moranguinho (cabelo marrom) e que, socialmente, poderíamos classificá-las como brancas. Notamos que as crianças que frequentam a creche são negras (Imagem 6). Esta imagem está colada na janela que dá acesso à secretaria da instituição. Observamos, bem ao fundo da Imagem 05, dentro da secretaria, a ilustração de uma garota branca colada ao mural.

Imagem 5. Creche Fúlvia Rosemberg.

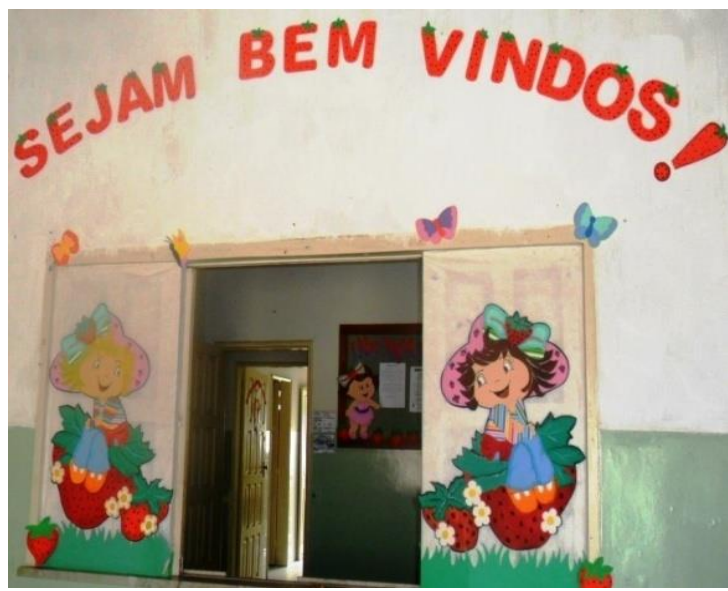

Fonte: Elaborado pelos autores.
Imagem 6. Creche Fúlvia Rosemberg.

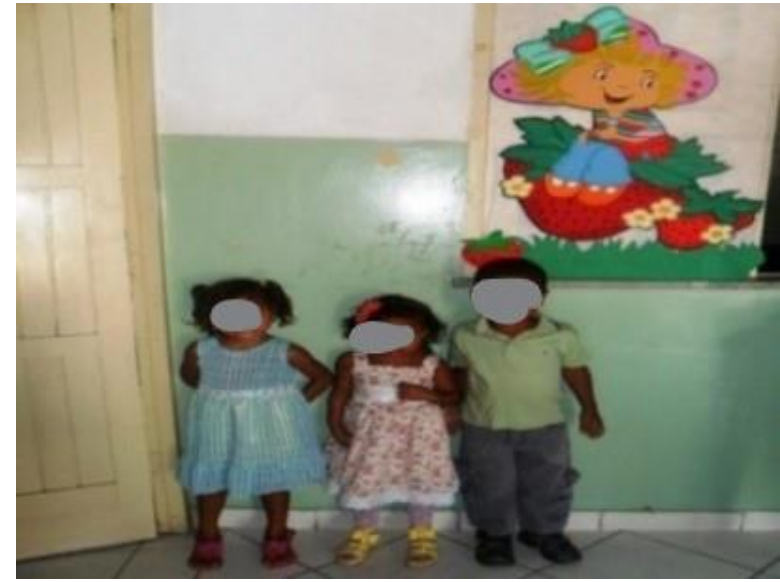

Fonte: Elaborado pelos autores.

A escola "impõe, a sim mesma, o dever de fazer de cada um de nós alguém; alguém com uma identidade bem definida pelos cânones na normalidade, os cânones que marcam aquilo que deve ser habitual, repetido, reto, em cada um de nós" (FERRÉ, 2011, p. 196). A diferença se constitui no "desvio, a inclinação até o não idêntico e nos afasta da identidade" .

Podemos destacar as múltiplas identidades e diferença pelas quais o sujeito é atravessado. O que é uma criança? Uma criança negra? Uma criança menina? Uma criança bonita? Uma criança brasileira? Nordestina? Baiana? Essas identidades são constituídas a partir 
do outro, de um ideal de criança, de beleza, de brasileiro, ou melhor, são estabelecidos com base em um modelo. E qual o modelo? Como a pessoa branca constrói a pessoa negra (FANON, 2008) de forma incompleta, quem constrói a criança e a mulher é o homem branco e, geralmente, as constrói de forma imperfeita - a mulher é a histérica; a criança, a pequena selvagem; a pessoa negra, a degenerada - pois ele, o homem branco, o eurocêntrico, o colonizador, o civilizado só enxerga a si mesmo e o outro como não igual, como não humano. Nesse sentido, reduz-se a diferença a nichos homogêneos e deixa marcada a diferença como resultado da história e das relações de poder. A outro, ao diferente, cabe ser respeitado e, até aceito, sem jamais ser enfrentado em sua potência.

É por inúmeras maneiras que o racismo aflora no sistema educacional - na ornamentação do espaço, na distribuição das imagens que compõem as salas, os corredores e as portas. O espaço escolar converteu-se em um espaço homogêneo e hierarquizado e de controle dos processos de ensino aprendizagem sob o qual se corrigem e normalizam os sujeitos. Existem muito poucas gravuras com as quais a criança preta ou parda (criança negra) possa se identificar. "Suas crenças, conhecimento, destrezas e valores são ignorados" (SANTOMÉ, 2012, 165).

$\mathrm{Na}$ Imagem 7, registrada na Escola Stuart Hall, que atende a crianças de 4 e 5 anos de idade (pré-escola), aparecem as gravuras de duas crianças brancas e uma criança negra e, à frente, um grupo de nove alunos/as todos com características de crianças negras. Talvez sejam declaradas da cor parda. Não há crianças loiras nesta sala de aula. No painel, as duas crianças brancas estão juntas, e a criança negra encontra-se afastada por uma árvore, no outro extremo do painel. Isso seria apenas uma coincidência, ou estaria relacionado ao isolamento da pessoa negra, à sua segregação, à sua exclusão?

Imagem 7. Pré-Escola Stuart Hall.

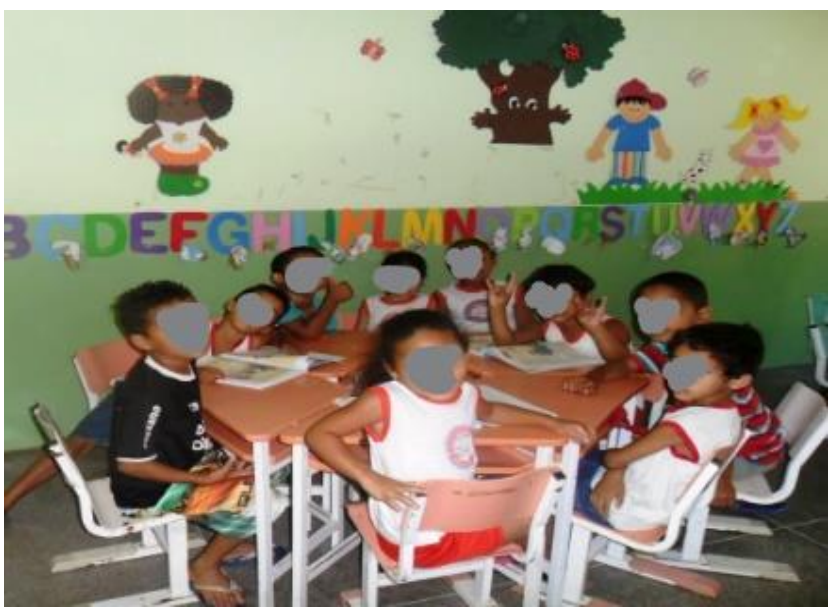

Fonte: Elaborado pelos autores. 
Por outro lado, podemos refletir sobre a presença de um personagem negro em meio a um número maior de personagens brancos. Se não existe criança loira, por que tanta necessidade de representá-la? Isso faz-nos lembrar de comerciais televisivos, seja de crianças, seja de adultos, em que as empresas exibem imagens de pessoas brancas de olhos azuis ou verdes e, ao final do comercial, aparece rapidamente uma pessoa negra, como se para justificar o não racismo da empresa - "Olha aí, colocamos uma pessoa negra no comercial, não somos racistas".

É possível ver que as crianças negras aparecem como ameaça à ordem social; são os inimigos da sociedade, os desprivilegiados, que não devem ser expostos. As escolas incorporaram temas como diversidade e diferença e corroboram os documentos oficiais e políticas públicas, mas, por outro lado, encaram a centralidade de personagens brancos/as com naturalidade. Ostentam a não superação do etnocentrismo e manifestam um discurso eurocêntrico, que condiciona o campo pedagógico.

Vejamos mais alguns exemplos (Imagens 8 e 9) que ilustram esse discurso. Numa sala de pré-escola, é costume o/a professor/a ter um varal em que são penduradas as atividades com prendedores de roupas. Acreditamos que a professora resolveu enfeitar os prendedores com rostinhos de crianças, para ficar mais organizado e bonito, mas fez isso com cabecinhas de crianças brancas. Não conseguimos visualizar nenhuma cabecinha com características de criança negra nos prendedores, embora a sala seja composta de mais de vinte crianças negras. Nesta sala, só conseguimos autorização para fotografar essas três crianças. Vejamos a imagem da direita, em que as cabecinhas aparecem de forma mais visível.

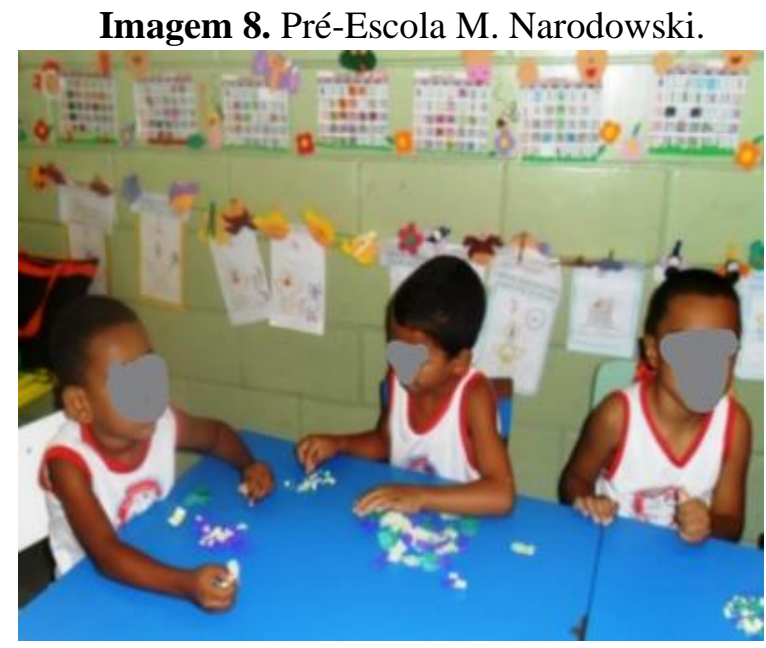

Fonte: Elaborado pelos autores.
Imagem 9. Pré-Escola M. Narodowski.

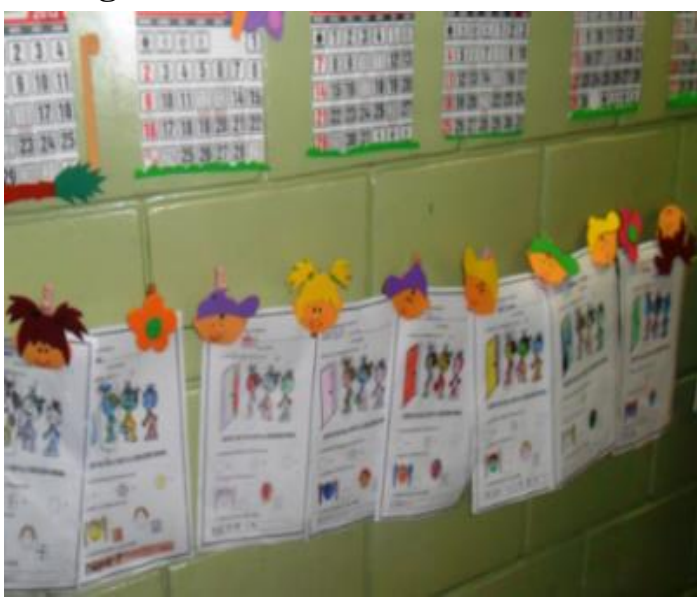

Fonte: Elaborado pelos autores.

Segundo Silva (2012), as estratégias pedagógicas para lidar com a identidade e a diferença têm se pautado em três categorias, assim classificadas: liberal, terapêutica e a de 
inspiração pós-estruturalista. Mas existe uma que se encontra no lugar intermediário entre a primeira (liberal) e a segunda (terapêutica).

A estratégia liberal, ao trabalhar com a diversidade, estimula e cultiva o sentimento de boa vontade. Segundo essa estratégia, a diversidade é constructo da natureza, é porque "nasceu assim"; Deus os criou desse jeito, e, por isso, devem ser respeitados ou tolerados, pois eles não têm culpa de ser como são. O problema é que essa abordagem "deixa de questionar as relações de poder e os processos de diferenciação que, antes de tudo, produzem a identidade e a diferença" (SILVA, 2012, p. 98).

A estratégia terapêutica posiciona a diversidade como boa e natural, mas atribui a rejeição da diferença e do outro a distúrbios psicológicos e, que por isso, as atitudes e os comportamentos preconceituosos e discriminatórios devem ser tratados, pois constituem desvio de condutas. A pedagogia e o currículo devem proporcionar atividades e exercícios de conscientização para que os/as estudantes mudem os seus comportamentos e as suas atitudes (idem).

A estratégia intermediária baseia-se na intercalação entre as duas primeiras e, conforme Silva, é a mais comum na rotina escolar e no currículo. Ela "consiste em apresentar aos estudantes e às estudantes uma visão superficial e distante das diferentes culturas". Para ela "o outro aparece sob a rubrica do curioso e do exótico" e não há questionamento das relações de poder que envolvem a identidade e a diferença, pois isso é feito de forma distante para não causar "nenhum risco do confronto e dissonância" (SILVA, 2012, p. 99).

E, por fim, a abordagem pós-estruturalista, segundo a qual a pedagogia e o currículo tratam a identidade e a diferença como questões políticas e produções culturais sedimentadas nas relações de poder e, por isso, não são fixas e imutáveis. "Antes de tolerar, respeitar e de admitir a diferença, é preciso explicar como ela é ativamente produzida" (idem).

Independente da estratégia utilizada, a pedagogia, o currículo, os/as professores/as precisam colocar tais temáticas no centro dos discursos da escola, com vistas a equacionar uma política de alteridade com seus múltiplos modos de endereçamentos ${ }^{2}$, pois não existe uma

\footnotetext{
${ }^{2} \mathrm{O}$ modo de endereçamento é um termo dos estudos do cinema com enorme peso político e teórico e é conceituado como algo que está no texto do filme que age, de alguma forma, sobre seus espectadores imaginados ou reais, ou sobre ambos. Os teóricos do cinema desenvolveram a noção de modo de endereçamento para lidar, de uma forma que fosse específica ao cinema, com algumas das grandes questões que atravessam os estudos de cinema, a crítica de arte e literatura, a sociologia, a antropologia, a história e a educação. Essas questões têm a ver com a relação entre o "social" e o "individual". Questões como: "qual é a relação entre o texto e um filme e a experiência do espectador, a estrutura de um romance e a interpretação feita pelo leitor, uma pintura e a emoção da pessoa que a contempla, uma prática social e a identidade cultural, um determinado currículo e sua aprendizagem? Os filmes, assim como as cartas, os livros, os comerciais de televisão, são feitos para alguém" (ELLSWORTH, 2001, p. 1114).
} 
estratégia certa, ou melhor, em todas correm-se riscos. Como os modos de endereçamento “erram" seus públicos, o currículo, a pedagogia, as estratégias de ensino também podem errar. Os sujeitos e as identidades são múltiplas; de forma análoga, as estratégias podem ser múltiplas, sem garantias de sucesso.

O poder de endereçamento

Não é, pois, o poder de obter, à vontade, respostas previsíveis e desejadas dos estudantes ou dos públicos. Não é o poder de posicionar os estudantes em algum desejado e preciso ponto do mapa de relações sociais. O poder de endereçamento não é algo que os professores possam dominar, controlar, predizer ou transformar em uma tecnologia. (ELLSWORTH, 2001, p. 43).

O currículo e a aprendizagem se conectam com linhas de fuga; não há como controlar o que o/a aluno/a vai ou não aprender, pois a aprendizagem se comunica com o improvável. Como lidar com as diferenças em espaços que são tão voláteis? É preciso pensar o sujeito para além dos binarismos, dualidades, como multiplicidade de lugares, de identidades, de diferenças. A problematização de temas como etnia e raça nos currículos vai além das discussões sobre o acesso, as cotas e um currículo que abarque essas questões, embora sejam questões importantes. Faz-se necessário problematizar o currículo, e não reduzir essas questões a temas transversais, como dia do índio, da consciência negra, mas torná-las centrais, como campo de conhecimento, poder e identidade.

Comumente vemos, nas instituições educativas, atividades fragmentadas e isoladas, às quais se dedica uma hora ou um dia para discutir e problematizar a cultura africana ou indígena, e, no resto do ano, não se fala mais no assunto. Essas atitudes possibilitam o estudo da diversidade cultural de forma isolada e esporádica.

Não obstante,

$\mathrm{Na}$ medida em que as relações de sala de aula são moldadas pelos antagonismos sociais e econômicos mais amplos bem como definidos pelas relações de gênero e raça, os educadores não podem cerrar o espaço da diferença entre endereçamento e resposta. Eles jamais podem impedir o medo, a fantasia, o desejo, o prazer e o horror que fervilham no espaço social e histórico entre endereçamento e resposta, currículo e estudante. (ELLSWORTH, 2001, p. 49).

A escola continua a instituir os espaços de cada sujeito e a indicar o que cada um pode e deve fazer. Ela aponta quem deve ser selecionado como modelo e qual o referencial a seguir. Se for selecionar uma criança para apresentar uma peça teatral, cantar, dançar, em geral escolhe a branca. Quando seleciona a criança negra, direciona-a a papéis subalternos. Ao longo da 
história, vemos que o lugar da pessoa negra é predeterminado e, hierarquicamente, os negros/as se posicionam atrás, e brancos/as à frente.

Dessa forma não dá para pensar um currículo isoladamente das tramas que se estabelecem no cotidiano escolar. É preciso atentar para o racismo e o etnocentrismo que estão presentes nos discursos por meio da linguagem, do olhar e das ações que manifestam relações de poder, nas quais estamos todos enredados, pois é na interação com o outro que vemos a diferença. O sujeito se constitui na relação com o outro pela mediação cultural. E ao manter essas relações, podemos experimentar e construir nossas subjetividades. Somos atravessados por várias experiências na condição de sujeitos. Coisas que acontecem conosco, sobre nós, fora de nós afetam a maneira de pensar, agir, sentir e viver. A experiência constrói o sujeito e sua subjetividade. Esta experiência envolve, claramente, princípios de alteridade.

A foto de um garoto ao lado do Papai Noel (Imagem 10) é bem interessante. A mãe fez questão de que tirássemos a foto do seu filho, que já apareceu em outra fotografia na discussão do tópico Imagem, memória e discurso. Era o final do ano de 2013, e a escola estava organizada para o encerramento das atividades letivas. A mãe, ao posicionar a criança junto ao Papai Noel, o tempo todo pedia para o filho dar risada. Observamos que essa mãe (negra), com seu comportamento e atitude, tem uma excelente dose de autoestima e um olhar positivo em relação à pessoa negra, o que foi percebido na atitude da criança, que fez questão de sair na fotografia. Optamos por usar esta foto para mostrar que o Papai Noel também, aparentemente, é branco.

Imagem 10. Creche Maria Bujes.

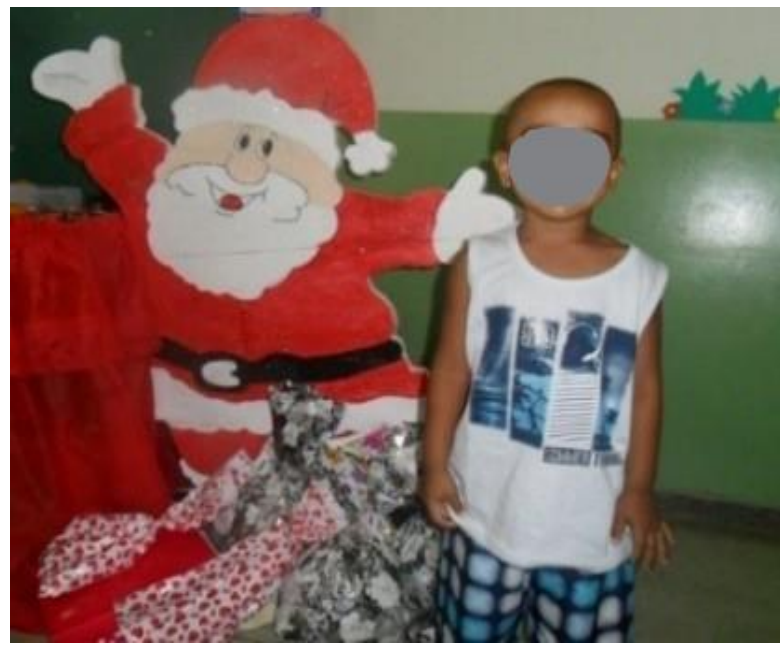

Fonte: Elaborado pelos autores. 
Se a escola fabrica sujeitos, subjetividades, identidades; se a disciplina é produtiva, então como se dão essas construções na educação infantil ? Observamos que o processo de fabricação dos sujeitos é continuado e geralmente muito sutil. Porém, se

\begin{abstract}
Admitirmos que a escola não apenas transmite conhecimentos, nem mesmo apenas os produz, mas que ela também fabrica sujeitos, produz identidades étnicas, de gênero, de classe; se reconhecemos que essas identidades estão sendo produzidas através de relações de desigualdade, se admitirmos que a escola está intrinsecamente comprometida com a manutenção de uma sociedade dividida e que faz isso cotidianamente, com nossa participação ou omissão; se acreditamos que a prática escolar é historicamente contingente e que é uma prática política, isto é, que se transforma e pode ser subvertida; e, por fim, se não nos sentimos conformes, então certamente, encontramos justificativas não apenas para observar, mas, especialmente, para tentar interferir na continuidade dessas desigualdades (LOURO, 2012, p. 89-90).
\end{abstract}

A escola precisa valorizar uma estética negra que extrapole o glamour da TV. A estética negra necessita se propagar nos telejornais e novelas brasileiras, e não apenas no carnaval carioca, em que a mulher negra exibe a sua sensualidade. Precisa ser incorporada, no cinema, aos desenhos animados, na literatura infantil, nos muros e paredes das escolas.

Vale questionar por que os sujeitos, a raça, a sexualidade sempre são caracterizados, discutidos como isso ou aquilo, verdadeiro ou falso, legal ou ilegal, vez que as pessoas negras e as brancas, o mundo e o submundo, o normal e o patológico estão sempre separados por uma linha imaginária. Nos discursos racializados, tudo o que não pode ser pensado em termos científicos, civilizados, desenvolvidos cairá no colonialismo do sem lei e sem regra, um estado de natureza que caracteriza a dominação patriarcal e colonial hegemônicas.

Vemos que a escola reproduz esse paradigma quando separa alunos/as fortes e fracos/as, como a sociedade também opera nessa lógica quando, binariamente, separa homem e mulher, hetero e homo, criança e adulto, negro/a e branco/a, europeu/ia e africano/a e/ou latino/a, enfim. Os discursos da escola, como inclusiva e aberta, que integra harmonicamente as diferenças, caem por terra diante de todas as imagens mostradas no decorrer deste capítulo. Os regimes de verdade constroem esse "outro" (negro/a) como objeto colonial.

\title{
Considerações Finais
}

As imagens analisadas delineiam um retrato revelador dos discursos do branqueamento e fornecem elementos para compreendermos as violências raciais que se fazem presentes nas escolas. Ressoam, na nossa sociedade, na escola e nas pedagogias empregadas no contexto escolar, situações marcadamente racistas. Não são raras as situações de discriminação que as 
crianças enfrentam como pudemos apresentar no decorrer deste trabalho. O preconceito racial e o racismo manifestam-se nas relações pessoais, institucionais, na mídia, nas empresas, escolas, universidades, nos currículos escolares, nas salas de aula, nos livros didáticos, nas livrarias. É preciso manter a denúncia e luta por melhores condições de vida para nossas crianças.

A falta de problematização dos temas diversidade, discriminação e racismo no dia a dia da escola e o comportamento silencioso e acrítico dos adultos diante das situações discriminatórias podem levar muitas crianças a cristalizar aprendizagens. É preciso educar para o respeito à diversidade étnico-racial, buscando uma "pedagogia multirracial" (ARROYO, 2007), pois é dever da escola eliminar toda forma de racismo instituído.

As creches e pré-escolas se constituem em ambientes ricos para observarmos como as crianças pequenas formam a sua identidade étnico-racial. A educação infantil tem o papel de possibilitar à criança o desenvolvimento do senso crítico, para que possa experimentar outros valores, respeitar a pluralidade étnico-racial. O racismo e os processos discriminatórios devem ser colocados em discussão diuturnamente.

\section{REFERÊNCIAS}

ARROYO, Miguel Gonzalez. Pedagogia multirracial popular e o sistema escolar. In: GOMES, Nilma Lino. Um olhar além das fronteiras: educação e relações raciais. Belo Horizonte: Autêntica, 2007.

BRAH, Avtar. Diferença, diversidade, diferenciação. Cadernos Pagu. n. 25, p. 329-376, jan.jun. 2006.

ELLSWORTH, Elizabeth. Modos de endereçamento: uma coisa de cinema; uma coisa de educação também. In: SILVA, Tomaz Tadeu da. Nunca fomos humanos: nos rastros do sujeito. Belo Horizonte: Autêntica, p. 7-76, 2001.

DICIONÁRIO ANALÓGICO DA LÍNGUA PORTUGUESA: IDÉIAS AFINS. Rio de Janeiro: Lexikon, 2010.

FANON, Frantz. Pele negra, máscaras brancas. Salvador: EDUFBA, 2008.

FERRÉ, Nuria Pérez de Lara. Identidade, diferença e diversidade: manter viva a pergunta. In: LARROSA, Jorge; SKILIAR, Carlos. (orgs.). Habitantes de Babel: políticas e poéticas da diferença. Belo Horizonte: Autêntica, p. 195 - 213, 2011.

FOUCAULT, Michel. Vigiar e punir: nascimento da prisão. Tradução de Raquel Ramalhete. Petrópolis, Vozes, 1987.

HALL, Stuart. A Identidade cultural na pós-modernidade. Rio de Janeiro, DP\&A, 2004. 
HALL, Stuart.. Quem precisa de identidade. In: SILVA, Tomaz Tadeu da (org). Identidade e diferença: a perspectiva dos estudos culturais. Petrópolis, RJ: Vozes, p. 103-133, 2012.

KOSSOY, Boris. Fotografia \& história. São Paulo: Ateliê Editorial, 2012.

LOURO, Guacira Lopes. A escola e a pluralidade dos tempos e espaços. In: COSTA, Marisa Vorraber. Escola Básica na virada do século: cultura, política e currículo. São Paulo: Cortez, p. $73-106,2002$.

LOURO, Guacira Lopes. Gênero, sexualidade e educação: uma perspectiva pósestruturalista. Petrópolis, RJ: Vozes, 2012.

LOURO, Guacira Lopes.. Pedagogias da sexualidade. In: O corpo educado: pedagogias da sexualidade. Belo Horizonte: Autêntica, p. 7 -34, 2013.

MACEDO, Elizabeth. A cultura e a escola. In: MISKOLSI, Richard (org.). Marcas da diferença no ensino escolar. São Carlos, SP: EdUFSCar, p. 09 - 37, 2010.

MANGUEL, Alberto. Lendo imagens: uma história de amor e ódio. São Paulo: Companhia das Letras, 2001.

SANTOMÉ, Jurjo Torres. As culturas negadas e silenciadas no currículo. In: SILVA, Tomaz Tadeu da. (org.). Alienígenas na sala de aula: uma introdução aos estudos culturais em educação. Tradução de Tomaz Tadeu da Silva. Petrópolis, RJ: Vozes, 2012, p. 155 - 172.

SARGENTINI, Vanice Maria Oliveira; RIBEIRO, Jocenilson; SOUZA, Parla Camila. Materialidades discursivas no ensino de Língua portuguesa: a pesquisa com novas linguagens. Revista Linha D’água, n. 25, p. 203-226, 2012.

SILVA, Antonio Luiz da. Pluralidade e diversidade: pensar sobre a diferença e a sua emergência na escola. Revista Lugares de Educação, Bananeiras/PB, v. 3, n. 6, p. 197-213, Jul.-Dez., 2013. Disponível em:

http://periodicos.ufpb.br/ojs/index.php/rle/article/download/15801/9360. Acesso em 09 jul. 2020.

SILVA, Tomaz Tadeu. A produção social da identidade e da diferença. In: Identidade e diferença: a perspectiva dos estudos culturais. Petrópolis, RJ: Vozes, p 73-102, 2012.

SILVÉRIO, Valter Roberto. Raça e racismo na virada do milênio: novos contornos da racialização. Tese de Doutorado. Campinas, SP: 1999

\section{SOBRE OS AUTORES:}

\section{Edmacy Quirina de Souza}

Doutora em Educação pela Universidade Federal de São Carlos - UFSCar; professora da Universidade Estadual do Sudoeste da Bahia - UESB; atua no Programa de Pós-Graduação em Educação - PPGEd - UESB; Vice-Líder do Grupo de Pesquisa em Infância, Educação e Contemporaneidade - GPIEC. E-mail: macy.souza@ hotmail.com

(iD https://orcid.org/0000-0002-6712-1021 


\section{Nilson Fernandes Dinis}

Doutor em Educação pela Universidade Estadual de Campinas - Unicamp; professor associado da Universidade Federal de São Carlos - UFSCar; atua no Programa de Pós-Graduação em Educação - PPGE - UFSCar. E-mail: ndinis@ufscar.br

(iD https://orcid.org/0000-0002-8596-1577 